\title{
Natural parasitism of Trichogramma pretiosum (Hymenoptera: Trichogrammatidae) in Neoleucinodes elegantalis (Lepidoptera: Crambidae) eggs on tomato (Solanales: Solanaceae) in the Northeast region, Brazil
}

\author{
R. C. M. Oliveira ${ }^{a, b^{*}}$ (D), P. L. Pastori ${ }^{a, b}$ (D), C. R. Coutinho (D), S. O. Juvenal $^{b}$ (D) and \\ C. V.S. Aguiar $^{b}$
}

\begin{abstract}
aPrograma de Pós-graduação em Agronomia/Fitotecnia, Universidade Federal do Ceará - UFC, Av. Mister Hull, 2977, CEP 60356-001, Fortaleza, CE, Brasil

bLaboratório de Entomologia Aplicada, Universidade Federal do Ceará - UFC, Av. Mister Hull, 2977, CEP 60356-001, Fortaleza, CE, Brasil

*e-mail: ruan.carlos@yahoo.com.br
\end{abstract}

Received: July 04, 2018 - Accepted: February 18, 2019 - Distributed: May 31, 2020

The tomato fruit borer, Neoleucinodes elegantalis (Guenée, 1854) (Lepidoptera: Crambidae) is considered one of the main pests of the tomato crop, causing direct damage to the fruit, with losses ranging from $20 \%$ to $100 \%$ (Picanço et al., 2007). Its occurrence was observed in 1922 in the State of Ceará and in 1939 in São Paulo, and later it was found disseminated in almost all tomato producing regions of Brazil (Carneiro et al., 1998). The female of $N$. elegantalis preferably lays the eggs at the base of green fruits, after emergence, larvae rapidly penetrate and develop within the fruit (Eiras and Blackmer, 2003). Because of the insect habit, which makes its control difficult, a viable alternative is the use of Trichogramma spp. (Hymenoptera: Trichogrammatidae), because they parasitize the eggs, thus preventing the emergence of the larvae and the damage caused by them (Parra and Zucchi, 2004).

Successful commercial release biological control programs using Trichogramma spp. and others parasitoids, require researches that involves the collection, correct identification, selection of the best species and/or lineages best suited to the region (Parra et al., 2002; Pereira et al., 2011). Each species and/or lineage of Trichogramma spp. have particularities that make them unique and thus may present variations in the adaptation to the environment, parasitoid's ability to "search", parasitism capacity and overcome the mechanisms of pest defense, such as the physical barriers in the Spodoptera frugiperda (J.E. Smith, 1797) (Lepidoptera: Noctuidae) egg mass (Parra and Zucchi, 2004; Beserra et al., 2005; Colazza et al., 2010).

Studies on egg parasitoids in Northeast Brazil have been ignored in recent years (Souza et al., 2016). In Northeast, only three species were reported: Trichogramma atopovirilia Oatman \& Platner, 1983 (Hymenoptera: Trichogrammatidae) in Alabama argillacea eggs (Hübner, 1818) (Lepidoptera: Noctuidae); Trichogramma galloi Zucchi, 1988 (Hymenoptera: Trichogrammatidae), in Diatraea saccharalis (Fabricius, 1794) (Lepidoptera: Crambidae) eggs; Trichogramma pretiosum Rilley, 1879
(Hymenoptera: Trichogrammatidae) in Spodoptera spp., Tuta absoluta (Meyrick, 1917) (Lepidoptera: Gelechiidae) and $A$. argillacea eggs (Bleicher and Parra, 1989; Pratissoli and Parra, 2001; Querino et al., 2016). This being, until then, the only report of natural occurrence of Trichogramma spp. in the Ceara State. Carneiro et al. (1998) carried out a research with releases of $T$. pretiosum for the control of $N$. elegantalis in Tiangua-CE, however it was used Trichogramma strains from the region of Petrolina-PE.

Thus, the present study investigated the natural occurrence of parasitoids of the genus Trichogramma in $N$. elegantalis eggs in commercial tomato farms in the Ibiapaba region, Ceará, Brazil, one of the major producing area of vegetables in the Northeast. $N$. elegantalis eggs were collected in three tomato production areas, in the Serra da Ibiapaba region, Northwestern Ceará State, Guaraciaba do Norte $\left(04^{\circ} 10^{\prime} \mathrm{S}\right.$ and $\left.40^{\circ} 44^{\prime} \mathrm{W}\right)$, Ubajara (03 $51^{\circ} \mathrm{S}$ and $40^{\circ} 55^{\prime} \mathrm{W}$ ) and Croatá $\left(04^{\circ} 24^{\prime} \mathrm{S}\right.$ and $\left.40^{\circ} 54^{\prime} \mathrm{W}\right)$, from 2015 to 2017 .

Eggs were randomly collected from tomato plants in areas of organic and conventional production systems. Fruits containing parasitized eggs were collected and sent to the "Laboratório de Entomologia Aplicada (LEA)" of the "Universidade Federal do Ceará (UFC)". Under a stereoscopic microscope, a small piece of the skin of the fruit containing the eggs was removed and inserted into a glass tube $(8.5 \times 2.5 \mathrm{~cm})$, kept at $25.0 \pm 2.0^{\circ} \mathrm{C}, 70 \pm 10 \%$ relative humidity and $12 \mathrm{~h}$ photophase, and observed until the parasitoids emerged or the larvae hatched. The adults were sexed and preserved in ethanol (70\%) for later identification. Trichogramma males were prepared, mounted on slides and identified by Fabrício Fagundes Pereira, D. Sc., at the "Universidade Federal da Grande Dourados (UFGD)" with collaboration by Ranyse Barbosa Querino da Silva, D. Sc., at the "Empresa Brasileira de Pesquisa Agropecuária".

Trichogramma pretiosum (Hymenoptera: Trichogrammatidae) was the species obtained from the 
Table 1. Natural parasitism of Trichogramma pretiosum (Hymenoptera: Trichogrammatidae) on tomato-borer Neoleucinodes elegantalis (Lepidoptera: Crambidae) eggs in tomatoes in the Ibiapaba region, Ceará State, Norteast, Brazil.

\begin{tabular}{cccccc}
\hline Year & Planting system & Municipality & Total of eggs & Parasitized eggs & Parasitism (\%) \\
\hline 2015 & Conventional & Ubajara & 23 & 3 & 13.0 \\
2016 & Organic & Guaraciaba do Norte & 67 & 10 & 14.9 \\
2017 & Conventional & Croatá & 58 & 11 & 19.0 \\
\hline
\end{tabular}

N. elegantalis eggs collected in tomato areas of conventional and organic production systems in the Ibiapaba region. The percentage of parasitism in conventional production areas was $13 \%$ and $19 \%$ in Ubajara and Croatá, respectively, whereas in the organic area, located in Guaraciaba do Norte, the average observed parasitism was $14.9 \%$ (Table 1). The present study is the first to report the natural parasitism of $T$. pretiosum on $N$. elegantalis eggs in the Northeast region of Brazil. This is an important information in the effort to reveal the occurrence of Trichogramma spp. in the region and an essential step for the conservation of these parasitoids and their use in programs of applied biological control.

\section{Acknowledgement}

We are grateful to Fabrício Fagundes Pereira, D. Sc. and Ranyse Barbosa Querino da Silva, D. Sc., for the identification of T. pretiosum, to the rural producers for allowing the collection of the fruits in their properties, the "Conselho Nacional de Desenvolvimento Científico e Tecnológico (CNPq)" and the "Fundação Cearense de Apoio ao Desenvolvimento Científico e Tecnológico (FUNCAP)" for financial support.

\section{References}

BESERRA, E.B., DIAS, C.T. and PARRA, J.R., 2005. Behaviour of Trichogramma atopovirilia Oatman \& Platner and T. pretiosum Riley (Hymenoptera: Trichogrammatidae) on Spodoptera frugiperda (J. E. Smith) (Lepidoptera: Noctuidae) egg masses. Brazilian Journal of Biology $=$ Revista Brasileira de Biologia, vol. 65, no. 1, pp. 9-17. http://dx.doi.org/10.1590/ S1519-69842005000100003. PMid:16025898.

BLEICHER, E. and PARRA, J.R.P., 1989. Espécies de Trichogramma parasitoides de Alabama argillacea. Biologia de três populações. Pesquisa Agropecuária Brasileira, vol. 24, no. 8, pp. 929-940.

CARNEIRO, J.S., HAJI, F.N.P. and SANTOS, F.A.M., 1998. Bioecologia e controle da broca pequena Neoleucinodes elegantalis. Teresina: Embrapa Meio Norte, 14 p. Circular Técnica, vol. 26.

COLAZZA, S., PERI, E., SALERNO, G. and CONTI, E., 2010. Host searching by egg parasitoids: Exploitation of host chemical cues. In: F. L. CÔNSOLI, J.R.P. PARRA, R.A. ZUCCHI, eds. Egg parasitoids in agroecosystems with emphasis on Trichogramma. Dordrecht: Springer, pp. 97-147.

EIRAS, A.E. and BLACKMER, J.L., 2003. Eclosion time and larval behaviour of the tomato fruit borer, Neoleucinodes elegantalis (Guenée) (Lepidoptera: Crambidae). Scientia Agrícola, vol. 60, no. 1, pp. 195-197. http://dx.doi.org/10.1590/S010390162003000100030 .

PARRA, J.R.P. and ZUCCHI, R.A., 2004. Trichogramma in Brazil: Feasibility of use after twenty years of research. Neotropical Entomology, vol. 33, no. 3, pp. 271-281. http://dx.doi.org/10.1590/ S1519-566X2004000300001.

PARRA, J.R.P., BOTELHO, P.S.M., CORREA-FERREIRA, B.S. and BENTO, J.M.S., 2002. Controle biológico no Brasil: parasitóides e predadores. São Paulo: Editora Manole, 609 p.

PEREIRA, F.F., ZANUNCIO, J.C., OLIVEIRA, H.N., GRANCE, E.L.V., PASTORI, P.L. and GAVA-OLIVEIRA, M.D., 2011. Thermal requirements and estimate number of generations of Palmistichus elaeisis (Hymenoptera: Eulophidae) in different Eucalyptus plantations regions. Brazilian Journal of Biology $=$ Revista Brasileira de Biologia, vol. 71, no. 2, pp. 431-436. http:// dx.doi.org/10.1590/S1519-69842011000300012. PMid:21755160.

PICANÇO, M., BACCI, L., CRESPO, A.L.B., MIRANDA, M.M.M. and MARTINS, J.C., 2007. Effect of integrated pest management practices on tomato production and conservation of natural enemies. Agricultural and Forest Entomology, vol. 9, no. 4, pp. 327-335. http://dx.doi.org/10.1111/j.1461-9563.2007.00346.x.

PRATISSOLI, D. and PARRA, J.R.P., 2001. Seleção de linhagens de Trichogramma pretiosum Riley (Hymenoptera: Trichogrammatidae) para o controle das traças Tuta absoluta (Meyrick) e Phthorimaea operculella (Zeller) (Lepidoptera: Gelechiidae). Neotropical Entomology, vol. 30, no. 2, pp. 277282. http://dx.doi.org/10.1590/S1519-566X2001000200011.

QUERINO, R.B., SILVA, N.N.P. and ZUCCHI, R.A., 2016. Trichogramma na Amazônia: visão geral e potencialidades. In: N.M. SILVA, R. ADAIME, R.A. ZUCCHI, eds. Pragas agrícolas eflorestais na Amazônia. Macapá: Embrapa Amapá, pp. 597-606.

SOUZA, A.R., GIUSTOLIN, T.A., QUERINO, R.B. and ALVARENGA, C.D., 2016. Natural parasitism of Lepidopteran eggs by Trichogramma species (Hymenoptera: Trichogrammatidae) in agricultural crops in Minas Gerais, Brazil. The Florida Entomologist, vol. 99, no. 2, pp. 221-225. http://dx.doi.org/10.1653/024.099.0210. 